\title{
Dengue fever presenting as cauda equina syndrome
}

\author{
Jaslovleen Kaur, ${ }^{1}$ Jagandeep Singh Virk, ${ }^{2}$ Birinder Singh Paul, ${ }^{1}$ Kavita Saggar ${ }^{3}$
}

${ }^{1}$ Department of Neurology, Dayanand Medical College and Hospital, Ludhiana, Punjab, India ${ }^{2}$ Department of Orthopeadics, Government Medical College and Hospital, Chandigarh, India ${ }^{3}$ Department of Radiology, Dayanand Medical College and Hospital, Ludhiana, India

\section{Correspondence to Dr Jaslovleen Kaur, jaslovleen@gmail.com}

Accepted 4 July 2017

\section{DESCRIPTION}

Dengue is an arboviral disease transmitted by Aedes sp. mosquitoes. A wide spectrum of illness is observed, ranging from dengue fever to dengue shock syndrome. The common neurological complications noted are encephalitis and encephalopathy. Haemorrhagic complications due to thrombocytopenia can result in various neurological sequelae. ${ }^{1}$ We report a case of dengue fever with spontaneous spinal hematoma presenting as cauda equina syndrome.

A 47-year-old man presented with moderate grade fever and arthralgia for 5 days. On day 6 of illness, he got admitted with complaints of lower backache, urinary retention, bilateral lower limb weakness and numbness below ankle. This was followed by reduced perianal sensations. On clinical examination, the patient was found to have MRC grade 4/5 power in extensor hallucis longus and ankle plantar flexors. The ankle reflexes were absent bilaterally with other deep tendon reflexes

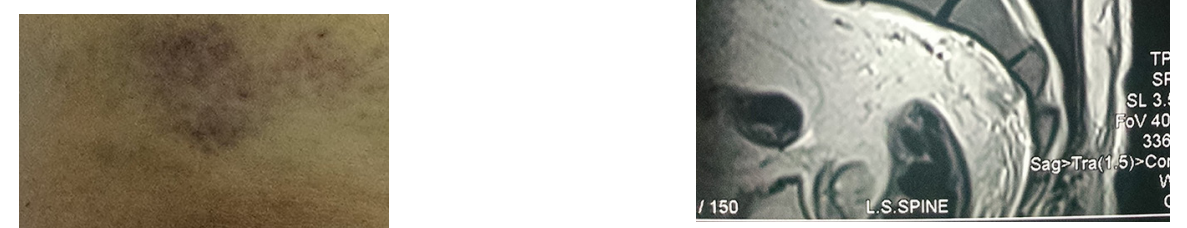

Figure 2 Large ecchymotic lesion on the anterior aspect of right thigh due to thrombocytopenia.

being normal. Babinski reflex was negative. The patient had decreased sensation to light touch and pinprick over the L5 and S1 dermatomes bilaterally. There was decreased sensation in the perianal region with a typical saddle-shaped distribution and a decreased bulbocavernosus reflex. The anal sphincter tone was also decreased with reduced wink on examining anal reflex. Since the patient had urinary incontinence, his bladder was catheterised on admission. All the clinical findings were consistent with a lower motor neuron type of lesion most likely in favour of cauda equina syndrome. MRI spine suggested spinal hematoma at the level of lumbar area (figure 1). His platelet count was 38000 at this time with multiple petechial rashes (figure 2). In view of spontaneous spinal hematoma and low platelet counts with history of fever, dengue serology was done. Dengue NS1 antigen and immunoglobulin $\mathrm{M}$ for dengue came out to be positive. Neurosurgical and orthopaedic consultation were sought and they advised for conservative management. Because of development of new petechial rashes and low platelet count, he required multiple blood and platelet transfusions. However, 
there was no improvement in urinary and perianal sensations. Over the course of 2-3 weeks, he made a slow recovery and his bowel bladder sensations improved. The motor and sensory deficit also improved over the course of time and the patient was able to ambulate independently at the time of his discharge. The

\section{Learning points}

- The neurological complications of dengue fever can occur with few or no signs of previous dengue infection.

- Early diagnosis can prevent many serious neurological complications in dengue fever. patient is now on regular follow-up in our outpatient department and has normal bowel bladder sensations with almost complete recovery of his motor and sensory parameters.

Contributors JK: Collection of data, conception and research. JSV: Structuring of case. BSP: Analysis and interpretation of data. KS: Imaging.

Competing interests None declared.

Patient consent Obtained from guardian.

Provenance and peer review Not commissioned; externally peer reviewed.

(C) BMJ Publishing Group Ltd (unless otherwise stated in the text of the article). All rights reserved. No commercial use is permitted unless otherwise expressly granted.

\section{REFERENCES}

1 Carod-Artal FJ, Wichmann O, Farrar J, et al. Neurological complications of dengue virus infection. Lancet Neurol 2013;12:906-19.

Copyright 2017 BMJ Publishing Group. All rights reserved. For permission to reuse any of this content visit http://group.bmj.com/group/rights-licensing/permissions.

BMJ Case Report Fellows may re-use this article for personal use and teaching without any further permission.

Become a Fellow of BMJ Case Reports today and you can:

- Submit as many cases as you like

Enjoy fast sympathetic peer review and rapid publication of accepted articles

- Access all the published articles

- Re-use any of the published material for personal use and teaching without further permission

For information on Institutional Fellowships contact consortiasales@bmjgroup.com

Visit casereports.bmj.com for more articles like this and to become a Fellow 